\title{
Securitizing Moves To Nowhere? The Framing of the European Union's Energy Policy
}

\section{Michal Natorski \& Anna Herranz Surrallés}

\begin{abstract}
In 2006, debates about 'energy security' reached the top of the EU's political agenda. A conjunction of political and economic factors seemed to be critically affecting the security of supply in most EU member states. A wide range of actors called for the establishment of a 'Common Energy Policy,' based on a fully operational Internal Energy Market and equipped with an external dimension enabling the EU to speak with one voice in the world. The results of this heated debate, however, fell short of these objectives. Informed by securitisation approaches, this article explores the debate over energy security that unfolded between 2005 and 2007. It aims to provide an understanding about why the framing of energy as a security issue did not mobilise enough support in favour of ground-breaking measures to tackle what was unanimously presented as a unique and especially hazardous situation. Specifically, the article will argue that those attempts to frame energy as a security issue in order to gain support for a Common Energy Policy have been of limited effect, precisely because the security framing contributed to the further legitimisation of EU member states' reluctance to cede sovereignty in the energy domain.
\end{abstract}

IN THE MID 2000s, A SERIES OF ECONOMIC AND POLITICAL DEVELOPMENTS IN WORLD energy markets converged, offering an especially disquieting picture. In market terms, the already rapidly growing world demand for energy reached an unexpected peak in 2004, with a growth rate that doubled the annual average growth rate of the preceding decade (Yergin 2006: 72). This demand shock was due, in part, to an annual increase of 16 per cent in China's demand of energy, thus supporting the fact that, with the ever-increasing demand from developing countries, notably in Asia, energy demand would soon grow faster than supply (Grevi 2006: 2). In the geopolitical terrain, the 2000s witnessed how the regions where the most important oil and gas reserves are located became particularly unstable. ${ }^{1}$ Political instrumentalisation of energy resources by major producers was also revealed as a great concern for European countries. The Russian-Ukrainian natural gas dispute that provoked

\footnotetext{
$165 \%$ of the world oil reserves are located in Middle Eastern countries from which many terrorist threats emanate. The situation in the region was aggravated at the beginning of 2000s due to the war in Iraq and the second Intifada in Palestine. Iran's nuclear programme caused another point of friction in the region. Finally, the major hydrocarbons producers in Latin American (Venezuela and Bolivia) suffered from different domestic tensions that affected their hydrocarbons sectors.
}

The authors would like to thank the participants of the UACES Workshop on 'Security of Energy Supply in the New Europe' that took place in September 2007 at the University of Glasgow, and especially Anke Schmidt-Felzmann, Valentina Feklyunina and Alasdair Young, as well as the Editor of JCER and an anonymous referee for their helpful comments. We also thank Amisha Shah for the language supervision.

ISSN 1815-347X online - Natorski, M. \& Herranz Surrallés, A. (2008). 'Securitizing Moves To Nowhere? The Framing of the European Union Energy Policy', Journal of Contemporary European Research, Vol. 4, No. 2, pp. 71-89. 
temporary cuts in supplies in some EU countries in January 2006 caused commotion in many European capitals, which until then had seen Russia as a reliable supplier. Unforeseeable events, such as natural catastrophes, accidents and terrorist attacks affecting energy infrastructure, also demonstrated the vulnerability of the tight global energy markets. For example, Hurricanes Katrina and Rita in August and September 2005, which affected areas of high concentration of oil infrastructure in the United States, were depicted as "the world's first integrated energy shock, simultaneously disrupting flows of oil, natural gas, and electric power" (Yergin 2006: 70). For EU representatives, all these trends that had been announced over the previous decades - fast growth in global demand of energy, increasing dependence on imports from unstable regions, but also rising energy prices and global climate warming suddenly appeared as 'serious risks' (Commission/SG/HR for the European Council 2006).

Against this background, between 2005 and 2007 the EU's political agenda prominently featured debates over energy security. All EU institutions and member states put forward their proposals for a more integrated energy policy, a 'Common Energy Policy' (CEP) in the terms used by the Commission (Piebalgs 2006d), or a 'New Energy Policy' (NEP) as the Council posited (Council of the European Union 2006i, 2006j, 2006k). Likewise, all institutions made a case, in one way or another, for the development of an external dimension of the European Energy Policy in order to enhance the external security of energy supplies to the EU (Commission of the European Communities/SG/HR for the European Council 2006; Commission of the European Communities 2006b). In this regard, the European Parliament even spoke in favour of a 'Common foreign energy policy strategy' (European Parliament 2006b). This was essentially a recognition of the fact that energy supply could not be dealt with only within the market sphere, but also needed a strategic, foreign policy approach, enabling the EU to maintain a unitary position in international energy relations. The necessity of setting new instruments to govern energy at the EU level was also supported by an important part of the scientific community (Geden et al. 2006: 25-29; Harks 2006; Westphal 2006; Baran 2007; Correljé and van der Linde 2006; Mañé-Estrada 2006; Weisser 2007).

Paradoxically, however, this broad consensus over the need for a more integrated energy policy ran parallel with EU member states' reinforced trend to affirm their own national energy policies. Particularly, big member states continued favouring their large national energy companies (national champions), contravening Internal Market rules and provoking intergovernmental disputes such as the Spanish-German conflict about the takeover of Endesa by E.ON that broke out at the end of 2006. Member states' bilateral strategies to secure their energy supply also caused major intra-EU tensions and mutual accusations of a lack of solidarity. Two particularly controversial cases in this regard have been Germany's bilateral agreement with Russia to build a North European Gas Pipeline, now known as 'Nord Stream' under the Baltic Sea without intermediaries; and Hungary and Italy's deals with Gazprom to build the 'South Stream' pipeline to the detriment of the Nabucco pipeline, one of the main European projects for diversifying the sources of gas supplies to EU countries. ${ }^{2}$

This article explores the debate that unfolded between 2005 and 2007 within the EU, as a means to help understand this gap between the unparalleled consensus for taking a quantum leap forward towards a Common Energy Policy and EU member states' affirmation of their national energy strategies. This article examines what different actors within the EU actually mean by energy security and explains why discourses by the European Commission and the Parliament about energy were not able to mobilise support in favour of significant, ground-breaking measures to tackle the gloomy prospects for energy supply to EU countries. The article begins by contextualising the debate over a European Energy Policy,

\footnotetext{
2 The planned Nord Stream Pipeline will directly connect Vyborg (Russia) with Greifswald (Germany) through the Baltic Sea, avoiding the intermediaries of other transit routes from Russia to Germany, i.e. the Jamal Europa and Progress pipelines. The project, finally approved in 2005, is promoted by a holding of German companies and Gazprom. The Nabucco gas pipeline project is intended to connect the Caspian region via Turkey with Bulgaria, Romania, Hungary, Austria and other Central and Western European countries. As of June 2008, the Gazprom backed competing 'South Stream' pipeline is supported by Italy, Hungary, Bulgaria, Serbia, Greece and Slovenia. It is anticipated that Austria will also sign up as a partner.
} 
arguing that the context of the mid-2000s was particularly propitious for further steps towards a Common Energy Policy, both due to international political and economic developments and to the securitizing dynamics emerging in the energy domain. The sections that follow are dedicated to an analysis of the discourses of the following actors: the European Commission (and some Commissioners), the Council of the European Union (as well as the contribution of some member states) and the European Parliament. The concluding section summarises the debates about the meaning and consequences of the various discourses on energy security.

\section{Energy Meets Securitization}

Energy constituted the starting point of European integration, with the European Coal and Steel Community (ECSC) and Euratom treaties adopted in the 1950s. Yet, oddly enough, the European Communities had no clear competency in the hydrocarbons sector, although oil and gas soon gained a dominant position in the energy mix of most West European countries, replacing coal energy. ${ }^{3}$ The inclusion of the hydrocarbons sector within the domain of European integration has long been subject to struggles between member states defending their national competencies and monopolies in these strategic sectors and the European Commission favouring the establishment of an Internal Energy Market and a Common Energy Policy. The oil crisis in 1973 marked the beginning of a slow development of a European Energy Policy in the field of hydrocarbons, albeit until the late 1980s, this policy would only embrace non-legally binding guidelines and recommendations. The first remarkable leap forward in the process of developing a European Energy Policy was achieved with the Internal Market reforms introduced following the 'Single European Act'. Thus, at the beginning of the 1990s, the EU adopted a series of Directives leading to the integration of energy markets, most notably regarding the transit of electricity and natural gas through the major European networks, as well as the transparency of gas and electricity prices. ${ }^{4}$ The reforms introduced at the beginning of 2000 allowed for the further liberalization of the electricity and gas sectors in the EU member states. Throughout this period, the scope of the nascent European Energy Policy sector progressively enlarged to embrace environmental concerns, placing an emphasis on renewable energies and energy efficiency.

These progresses notwithstanding, there are still numerous issues that remain outside the scope of European integration. ${ }^{5}$ Indeed, as early as 1990, the European Commission had already proposed the inclusion of an entire chapter in the Treaty of the European Union on a 'Common Energy Policy,' pursuing the following objectives: security of supply in the EU; the stability of the energy market; progress towards the internal energy market; adoption of measures to be taken for all energy sources in the event of a crisis; and a high degree of environmental protection (Matláry 1997: 62). This inclusion was rejected by the member states and nowadays, it is still not possible to talk about a Common Energy Policy, much less

\footnotetext{
3 Coal constituted a basic source of total energy consumption in member states of the European Communities, but was substituted progressively by oil and gas. In 1950, coal provided 70 per cent of energy for consumption and oil 12 per cent, lignite 8 per cent, and primary electricity 8 per cent, In 1971, this situation had changed significantly with oil constituted 60 per cent of energy consumption, coal 20 per cent, gas 11 per cent, lignite 4 per cent and primary electricity 5 per cent. It is worth noting that despite initial expectations, nuclear power developed very slowly as a source of energy and in 1970, contributed only 1 per cent of energy consumption (Commission of the European Communities 1972: 3-4). In 2005, the Gross Inland Consumption of energy was made up of 17 per cent solid fuels, 36 per cent oil, 24 per cent natural gas, 14 per cent nuclear power, and renewable energy provided almost 7 per cent of energy (European Commission, Directorate-General for Energy and Transport 2008: 96).

${ }^{4}$ The Directives related to the transit of electricity and gas through the major European networks established that transit conditions negotiated between operators responsible for major networks and relevant bodies in member states should be non-discriminatory and impartial and must not contain unfair clauses and unjustified restrictions. The Directive on the transparency of gas and electricity prices for industrial end-users made compulsory the communication of prices data twice a year (Moussis 2004: 334).

${ }^{5}$ The European Commission, despite its insistence during the 1990s, failed to introduce the carbon tax as an element of energy policy (Matláry 1997: 68-71).
} 
consider an external dimension of the European Energy Policy, despite some small developments that will be discussed later in this article.

It has been argued that progress in developing both internal as well as external dimensions of the European Energy Policy was achieved mainly due to the 'windows of opportunity' brought about by external events (see Matláry 1997; Moussis 2004). The context of the mid 2000s, it was speculated, could work as another such window of opportunity. In fact, in 2006, alarm vis-à-vis changes in the world energy system appeared clearer than ever before and the concept of 'energy security' became one of the core elements of the energy debate. The words of the Energy Commissioner, Andris Piebalgs, show the dominance of this new framing:

\begin{abstract}
...over the past year we have seen the issue of security of energy supply become the issue of international relations. Across Europe, there has been a change in sentiment. Whereas previously the issue of security of supply was a technical issue reserved for the very specialised engineer or system operator, now the issue of energy security is on the table of every energy minister, as well as foreign, finance and industry ministers across Europe (Piebalgs 2006e) [Emphases added].
\end{abstract}

From the perspective of securitisation studies, speaking of security is a non negligible act. This is because presenting a public issue as a serious security threat means elevating this issue to an absolute priority, so that the logical consequence will be to take emergency measures or an exceptional course of action to face it (Buzan et al. 1998; Wæver et al. 1993). Employing security discursively is considered a politically-laden act also because it involves defining what legitimately deserves protection. Accordingly, basic concepts of securitisation approaches include securitising moves and referent objects. Securitising moves arise when a discourse takes the form of presenting something as an existential threat. These moves can lead to successful securitisation only if the relevant audience agrees with the given security discourse and its policy consequences. For security discourses to be accepted, it is essential that the audience attributes a high value to the issues identified as being threatened (the referent objects). However, it might also help that the threat-defence logic of the security discourse appears reasonable and the proposed measures workable. That is to say, the chain linking the causes and the consequences should be traceable and the proposed measures should convincingly appear capable of tackling the identified sources of threat.

The unprecedented debate about energy security in the EU together with the overall meagre outcomes of it opens many questions in this regard. Why did securitizing moves by different institutional actors not successfully activate the extraordinary measures to be expected from successful securitizations? What did different actors really mean when speaking about energy security? Were all speakers referring to the same threats and referent objects? Which actors employed a more securitizing rhetoric and for what purpose? Energy is a particularly elusive policy domain, since it can theoretically be framed in almost all the sectors identified in securitization studies (military, political, economic, societal and environmental). For example, a lack of energy resources can be conceived as a factor increasing the likelihood of military conflicts; as critically affecting economic performance; or certain inefficient uses of energy might be considered harmful for the environment. Similarly, referent objects might be placed over different levels, ranging from the individual (e.g. consumers) to the systemic level (e.g. global energy markets). In between, other intermediate levels of analysis are also possible in the case of energy security, for example the unit (e.g. national energy systems) or the level of the sub-system (e.g. EU internal market). The article endeavours to identify precisely which sectors of perceived threats and levels of referent objects actors were referring to and to analyse whether different definitions imply support for different measures to tackle the identified threats.

Securitization studies that have addressed European integration have mostly concluded that some of the decisive steps towards new areas of integration have been facilitated by successful securitizing moves. The Area of Freedom, Security and Justice, in particular, is a place where new security framings have been, for good or for bad, an important trigger for 
EU integrationist developments; for example, in migration and asylum policies (Huysmans 2000, 2006; Bigo and Guild 2005) or in police, justice and intelligence cooperation (Balzacq 2008; Bigo 1996; De Goede 2008; Guild 2008). Also in the foreign policy domain, some studies have argued that securitization mechanisms have contributed to some important policy developments; for example, EU eastern enlargement (Higashino 2004) or the European Neighbourhood Policy (Jeandesboz 2006). Hence, the question emerges of whether securitizing moves in energy policy, although not completely successful, did also contribute in one way or another to further integration in this domain. Such steps would crucially include the completion of deregulation and liberalisation of energy markets in member states; the establishment of new organs at the EU level to deal with energy such as EU regulatory agencies; or the setting up of an external dimension of a Common Energy Policy or at least well-built coordination mechanisms amongst EU member states, enabling them to elaborate common positions in international energy relations.

\section{European Commission Discourses on Energy}

Since the oil crisis of 1974, the European Commission has been advancing the notion of 'energy security' (Commission of the European Communities 1974). However, the Commission's approach to this topic was then circumscribed to economic and technocratic measures for harmonizing national energy policies. Conversely, the Commission's recent documents about the European Union's energy policy in general and its external dimension in particular (Commission of the European Communities 2006a, 2006b, 2007) ${ }^{6}$ have been characterized by a high securitising tone.

The basic sources of threat identified by the Commission are related to well known concerns about energy supply and dysfunctions in global energy markets: the growing dependency on energy imports and the concentration of reserves in only a few countries and regions, most of them unstable; the growing global demand for energy; the lack of reliable, affordable and sustainable flows of energy; and low reliability of suppliers, which may use energy as a political lever. In a nutshell, the Commission defined as threatening the fact that external actors do not 'play the same game' as the EU, thus reinforcing perceptions of instability. These observations were further aggravated by other uncertainties surrounding energy, such as the perspectives for global demand, price volatility, and the actual capacity of producer countries to supply the energy demanded due to the lack of necessary investments. In this context, divergences between member states, for example regarding policies towards Russia, and the lack of intra-EU solidarity in the event of a crisis were also considered a challenge for particular member states or the EU in general due to the fact that some countries are completely dependent on one source of energy supplies. All these energy-related threats are mainly of a market-economic nature, but may have consequences in broader terms: geopolitical security, economic stability, social development and climate change.

With all the aforementioned developments in mind, Commissioner Piebalgs (2006b) went so far as to declare that the world has entered into a "new energy era" that will last for the next few decades. This provoked a call for an urgent change in dealing with energy: "we are facing a period in which we have to get serious about the energy transition we are facing. We can either prepare it sensibly today, or risk being faced with a major crisis to our energy system

\footnotetext{
${ }^{6}$ The last significant document of the European Commission, before the fresh re-emergence of the energy debate, was issued in 2000 under the title 'Green Paper - Towards a European strategy for the security of energy supply' (Commission of the European Communities 2000). This document 'opened up a debate on energy policy unprecedented in the last 30 years' and encouraged the Commission to put forward some proposals concerning the regulation of energy efficiency, energy savings in buildings and fiscal and regulatory proposals to promote biofuels. However, the conclusion that "one message of the debate is to reflect on a global concept of security of supply" and for the European Union "is necessary to reinforce the co-ordination of the measures ensuring security of supply" was not followed in practice until the recent debate (Commission of the European Communities 2002: 9).
} 
for want of sufficient preparation" (Piebalgs 2006a). But on the other hand, the 'novelty' of the situation led him to elaborate on the lack of predictability in the energy sector, which is regarded as a source of political concern in itself. He argues for example that "global oil markets are not characterised by transparency and, put quite simply, we do not know how long oil will last, but we do know that the clock is ticking" (Piebalgs 2006c). Moreover, this uncertainty could be further aggravated by natural disasters or other accidents having a negative impact on energy, especially on prices and accessibility. The inability to make a rational and planned forecast of the energy situation through known free-market mechanisms exacerbates this perception of insecurity. But at the same time, this uncertainty discourse obscures the cause-effect relationship between the origin of threats and objects affected.

The definition of the referent objects in the documents presented by the Commission are somewhat diffuse, but focused at the sub-system level: the referent objects cover the European Union as a part of the world market; the competitiveness of the EU economies as a condition for consumers' (both individuals and businesses) well-being; and finally, the process of European integration itself, especially in its economic and international aspects. For example, the Communication, 'An Energy for Europe', from January 2007 recalls the origins of European integration in the Messina Declaration and stresses that "energy is essential for Europe to function" (Commission of the European Communities 2007). This discourse is complemented by a more global perspective, which acknowledges that the energy problem is not exclusively European, since "energy interdependence is becoming a global issue, with major shared concerns" (Piebalgs 2006a). But overall one may conclude that the need to protect EU competitiveness (and thus, European integration itself) was the dominant framing.

The discourses of other Commissioners clearly show a relationship with their institutional responsibilities. The discourse of Stavros Dimas, the Commissioner responsible for environmental policy, is structured around the threat of the consequences of climate change which may affect, especially in environmental and social terms, not only Europe but also the global level. For his referent object (environment, broadly considered), energy (or better, the misuse of energy) is considered a source of threat that should be faced 'urgently', 'decisively' and 'quickly' (Dimas 2005, 2006a, 2006b). In turn, Nelie Kroes, the Commissioner responsible for competition policy, focuses on a market and economy approach. The threats coming from outside the European Union are possible shortages of supply and trends observed in the global energy market. However, Kroes emphasises the problems related with the development of the Internal Energy Market. In this regard, a threat to EU competitiveness is market concentration, which leads to a lack of investment in infrastructure, a lack of consumer choice, lack of interconnections and thus, non-market regulated prices for energy (Kroes 2006a, 2006b).

Consistent with the Commission and various Commissioners' identification of the referent object at the level of the EU, the proposed measures are also EU-wide and go in the direction of greater integration in the energy field. Crucially, some of the measures proposed to alleviate the weaknesses of the European Energy Policy implied Member States' pooling of sovereignty in sensible issues such as energy infrastructure or the energy mix. Regarding infrastructure, the Commission proposed the establishment of a European Energy Regulator that would have decision making powers to establish common rules and approaches such as a European grid code to facilitate cross-border trade in electricity and gas ${ }^{7}$ (Commission of the European Communities 2006a: 6). Furthermore, in reference to the energy mix, the Commission indirectly suggested the limitation of Member States' sovereignty in choosing

\footnotetext{
${ }^{7}$ As an alternative to the European Energy Regulator, the Commission proposed the establishment of a European Centre for Energy Networks, thus formalizing intergovernmental cooperation between national transmission system operators. Other institutional proposals of the Commission were the establishment of the Energy Correspondents' Network and the European Energy Supply Observatory. The first one would reinforce the cooperation between member states in cases of crises, since the later would monitor the energy markets.
} 
their own energy mix when proposing the establishment of 'a minimum level of the overall EU energy mix originating from secure and low-carbon energy sources' (Commission for the European Communities 2006a: 9). Other internal measures proposed by the Commission to increase security of supply were of a more conventional nature: further development of an Internal Energy Market through liberalizing and regulative measures, energy savings, energy efficiency and renewable energy and further research into energy technology.

The measures that the EU should undertake in its external energy policy also contain proposals pushing for further integration, although their scope and institutional linkage within the EU system remains ambiguous. The most far-reaching example is the decision of appointing European coordinators "to represent EU interest in key international projects" (Commission of the European Communities 2007: 19) in accordance with trans-European network guidelines approved in 2006 (Decision No. 1364/2006/EC). Another proposed mechanism for coordinating Member States' external energy policies, was the creation of the network of energy correspondents "to assist the EU's early response and reactions in case of energy security threats" (Commission of the European Communities 2006b: 6). The Commission also stressed the relevance of the principle of coherence in EU energy policy between different EU energy-related policies and between the EU and Member States, especially with reference to issues of sustainability and climate change. Diversification of energy supplies in terms of energy sources, geographical origin and transit routes also ranked high in the Commission's documents. Other methods proposed for increasing the security of supply include the establishment of dialogue and energy partnerships with producing, transitional and other consuming countries, the creation of a pan-European Energy Community, that is to say the extension of the European energy acquis communautaire to neighbouring countries with the main aim of "ensuring stable and predictable regulatory frameworks for [the] development of energy markets and for providing stable conditions for the necessary investment in the supply of hydrocarbons" (Piebalgs 2006f). These are however measures that were already in place before the beginning of the 'energy security' debate in late $2005 .^{8}$

At the level of international energy markets, the European Commission focused on describing how this area should be organized world-wide, establishing "a new energy system, based on effective collaboration between producers and consumers, efforts to increase energy efficiency worldwide and a quantum leap in the production of renewable and low carbon energy" (Piebalgs 2006g). Measures proposed are somewhat diffuse, but some examples include the promotion of an international agreement on energy efficiency or widening the geographic scope of the EU Emissions Trading Scheme (Commission of the European Communities 2006b).

All in all, the content of the measures proposed by the European Commission were not much different from earlier proposals or instruments already in place. However, they were presented in the new light of the threats and risks emerging from the changed situation of the energy markets. Therefore, security discourse seems to be more inclined towards giving political salience and a sense of urgency to the already known measures and convincing the target audience (member states) to effectively implement them. In the same vein, the discourse about the novel and insecure world energy system served as a background for the Commission to justify the need for new landmark decisions paving the way for a Common Energy Policy, including an external dimension.

\footnotetext{
${ }^{8}$ The Energy Community process, aimed at extending the EU's internal energy market to the South East European region, was initiated in 2002 and the Treaty was signed in October 2005. The proposal of its extension to other countries, e.g. Ukraine, was already considered in 2004. Although to a very different extent, the Energy Charter Treaty signed in 1994 - joining 51 states from the Eurasian space plus the European Communities - is also aimed at establishing a legal foundation for energy security, based on the principles of open, competitive markets and sustainable development.
} 


\section{European Parliament Discourses on Energy}

The European Parliament (EP) has also been very active in the debate on energy security since the early 1970s, by issuing various reports and resolutions on the topic. Individual MEPs and groups have also contributed to debates on energy policy issues through parliamentary questions. Since the Parliament became a directly elected body in 1979, about 250 parliamentary questions on energy policy have been posed to the Council or the Commission (42 of them directly related to the issue of energy supply). ${ }^{9}$ During 2006, two main resolutions on this specific topic were discussed and adopted by the European Parliament (European Parliament 2006a, 2006b). In both documents, the EP made clear the connection between energy and security in global and European terms and clearly spoke in favour of a Common Energy Policy. Compared to the Commission's documents, the Parliament's discourse was even more straight-forward in describing the sources of threat and their proposals more far-reaching in their integrationist content.

Regarding the sources of threat, the EP noted with considerable concern the EU's high level of energy-import dependency on a limited number of energy producers and supply routes, a situation that, in its view, poses a "serious risk to its stability and prosperity" (European Parliament 2006b). The EP expressed its concern about the political use of energy supplies and prices, aggravated by Russian disputes over energy prices with its neighbours, and talks of the possible establishment of 'gas OPEC', which would have a major medium- and longterm impact on gas prices and security of supply. In this situation, the EP developed an emergency discourse "urging the Commission and the member states to take very seriously the real danger of a deficit in gas supplies from Russia after 2010" which, in its view, would be brought on, among other things, by a lack of investment, excessive leakage and energy waste in the Russian domestic market (European Parliament 2006b). At the same time, observing the well known problem of the lack of competitiveness in the EU energy market, the EP blamed member states for their "protectionist support for national market leaders" that distorts the internal market (European Parliament 2006a).

Regarding the referent object, the documents of the Parliament stress the social dimension of energy policy, indicating that "rising energy prices not only affect the economy as a whole but, above all, the socially disadvantaged" and claim that "consumers must be placed at the centre of all future energy policies" (European Parliament 2006b). The EP's discourse is couched in terms of a holistic vision of the consequences of the disturbance to energy supply. This is evident, for example, in its statement that "energy security should be considered an essential component of the global security concept and has an increasing impact on the overall security of the European Union" (European Parliament 2006a). It also observes that "disturbances in the supply of energy may create instability and can endanger peace" and that "...precarious energy and climate security situation is frequently the trigger for international crises and conflicts, which have consequences for democracy, human rights and poverty" (European Parliament 2006b).

The Parliament's proposed measures were characterised by a high degree of specificity, especially regarding the global and EU external levels, with some proposals going even further than those of the Commission. Although political groups and individual MEPs maintained diverse positions on the topic during parliamentary debates, the positions expressed in the two resolutions analysed here contain a clear push for a Common Energy Policy, including what the Parliament calls a 'common foreign energy security strategy' (European Parliament 2006b). In fact, in its resolutions, the EP regretted that the Commission's "Green Paper does not propose new targets or advance concrete proposals that would respond to recent calls for a common energy policy" (European Parliament 2006a).

\footnotetext{
${ }^{9}$ The data come from EurLex (Term search of Eurovoc descriptor: energy policy and energy supply).
} 
At the level of the international energy system, the EP proposed three kinds of measures. The first, in line with the Commission, was the promotion of a dialogue between consumers and producers in order to define a global approach and strategies towards energy. But compared to the discourse of the Commission, the Parliament seems to adopt a more confrontational stance in that it calls for the joining of efforts from consuming countries to counterbalance the oligopoly on the production side (European Parliament 2006b). ${ }^{10}$ Secondly, the EP proposed more concrete measures to "promote rules and institutions at a global level in order to protect sources of energy as well as the well-functioning of energy markets". For example, concrete measures to promote energy efficiency at a global scale could include the setting of minimum efficiency standards for global goods such as cars, appliances, consumer electronics and office equipment, to be harmonised in phases, and the promotion, at a global level, of integration of environmental issues into transport and energy decisions (European Parliament 2006a). The EP also proposed the creation of an internationally recognised mediation system for cases of conflict and dispute concerning the delivery and distribution of energy, for example in the framework of the WTO; in concrete terms, the EP put forward a proposal for the EU to pioneer this mediation system by developing it first within the framework of its Neighbourhood Policy and also with other key supplier countries and then to promote it at a global level (European Parliament 2006a). Finally, the EP also proposed linking energy security to development policies, recalling the right of every person in the world to have access to basic energy services, as stated in the Millennium Development Goals. Measures to achieve such development goals regarding energy would include the incorporation of a greater number of programmes promoting clean and efficient energy in the EU's development policy. Concrete measures included for example the formal endorsement by the Commission of the Extractive Industry Transparency Initiative (EITI) and the development of a strategy to mainstream the principles of the EITI and the Corporate Social Responsibility Scheme into all agreements with third countries.

Regarding the EU's external measures for the protection of the EU's interests on the world stage, the EP insisted on the need to 'speak with one voice' to increase its leverage in negotiations with energy producing and consuming countries. Remarkably, the EP even proposed that the Commissioner for energy policy be put in charge of this task, with a clearly defined mandate, which could set out a long-term European energy planning vision (European Parliament 2006b). In the EP's view, the 'supreme aim' of this external energy policy should be a reduction of the EU's dependence on fossil fuels from a few large suppliers and the diversification of the sources of energy and transit routes. The EP also encouraged cooperation with other producer (Central Asia) and transit countries but specifically underlined its concerns about Russia and its reluctance to accept the rules stipulated in the Transit Protocol and the Energy Charter Treaty "ensuring future muchneeded foreign investment in Russia's energy infrastructure and ensuring an adequate gas supply to the EU in the future" (European Parliament 2006b). Furthermore, the EP proposed in more detail the principles and objectives of energy relations in a future agreement between the EU and Russia. ${ }^{11}$ Like the Commission, the EP indicated the relevance of the ENP and its mechanisms as well as the extension of the Energy Community Treaty to other countries. ${ }^{12}$ However, in the view of the EP, cooperation with producer and transit countries

\footnotetext{
${ }^{10}$ In the resolution of December 2006, however, the EP also stated that producer countries also needed to be engaged in this definition of a global approach to energy. The principles of these new forms of global energy dialogue should aim at making global energy markets stable, secure and transparent, and at the same time provide a continued boost in favour of clean energy sources and energy efficiency (European Parliament 2006b).

11 These are: the incorporation of WTO mechanisms for settlement of disputes between the EU and Russia and/or individual investors; mutual access to infrastructure; competition rules limiting the power of quasi-monopolistic companies which have not been unbundled having access to their respective energy markets; and an agreement to address the issue of technical failures in the third countries affecting cross-border supplies to a EU Member State.

${ }^{12}$ During the parliamentary debates, the MEP Charles Tannock, rapporteur of one of the main reports on the ENP in 2006, spoke in favour of including Kazakhstan in the ENP, based on energy security considerations: "I have repeatedly made a case for a stable Kazakhstan to join the ENP, as (...) could indeed supply not just oil and gas but also uranium to the European Union, as we will inevitably have to build more nuclear reactors to satisfy Kyoto and not be over-reliant on unstable regions of the world -such as the Middle East, Venezuela or Nigeria, to name but a few - for fossil fuels" (European Parliament 2006c).
} 
should also encompass policies promoting "democratic reforms, the development of civil society and social progress", which "will contribute substantially to long-term political stability, which is necessary for security in the supply and distribution of energy" (European Parliament 2006a). As to the Internal Market, the Parliament's proposals followed the Commission's line. The EP emphasised the need for member states to implement existing Internal Market provisions to avoid the formation of oligopolistic energy markets or market dominance. It also called on the member states to agree on concrete, measurable objectives on issues such as the development of renewable energies, energy efficiency or Kyoto-related commitments. Yet, criticisms were directed at the Commission for the lack of instruments provided to address the high level of oil dependency in the transport and aviation sectors which were identified as the main cause of Europe's biggest security of supply problems and also environmental damage.

Overall, during the three plenary debates about energy security that took place in 2006, several MEPs defended the urgency of adopting further integrative measures in the energy domain employing a high securitizing tone. However, a contradiction seemed to appear in the very definition of energy and the measures proposed, particularly in the external dimension of this policy. As mentioned above, the EP proposed far-reaching integrationist steps in the external energy policy, proposing a leading role for the Commissioner for Energy in international energy relations. Yet, during the debates, some of the MEPs that most maintained that energy had to be dealt with as a security issue, ended up with the conclusion that it should be regarded as a matter of the Common Foreign and Security Policy, and not so much as a Community policy issue. The following quote by Polish MEP, Jacek Saryusz-Wolski, exemplifies the difficulty of framing energy as a security issue without taking it out of the Community domain:

The problem should therefore be considered as a foreign and security policy issue and so, besides Commissioner Piebalgs, I would willingly address Mr Solana and Mrs Ferrero-Waldner. It is essential for the EU to develop a true external security policy dimension in relation to gas and oil deliveries, which is distinct from energy policies sensu stricto. We should not mix them up [emphases added] (European Parliament 2006c).

\section{Member States' Discourses on Energy}

The issue of energy security has only very recently been incorporated as a relevant matter on the Council's agenda. The intergovernmental debate on energy policy was encouraged by the informal meeting of Heads of State and Governments, held in Hampton Court in October 2005 , which marked the turning point in the intergovernmental debate about energy. At that meeting, energy security ranked high on the list of topics to reflect on the future path of European integration, and EU member states started to think about some kind of 'New European Energy Policy'. The already mentioned dispute over the prices of gas delivered from Russia to Ukraine and the ensuing Russian gas cut-off at the beginning of 2006, which affected not only Ukraine but also various member states of the EU, acted as catalysts for discussion in various configurations of the Council.

Some member states in particular acted as catalysts for this debate on energy security, by emphasising the geopolitical dimension of energy policy. For example, German representatives, in contrast to their country's traditional economic approach to energy issues, repeatedly spoke about energy as a serious geopolitical security challenge and called for the development a 'foreign energy policy' as a new policy category (Steinmeier 2006a; $2006 \mathrm{~b}, 2006 \mathrm{c}) .^{13}$ The main source of threat was the coupling of rising global demand of energy with the fact that the most energy resources are located in regions of the world

\footnotetext{
${ }^{13}$ It is relevant that the "White Book for Security Policy of Germany and the future of the Bundeswehr" of 2006 included 'Energy security' as a section in its own. It established that "for the future of Germany and Europe, a sustainable and competitive energy supply is of strategic importance" (Bundesministerium der Verteidigung 2006: 17)
} 
characterised by political instability. ${ }^{14}$ The German foreign minister insisted on the need to find energy security means not only for EU countries but also for all producing, transit and consumer countries, especially on the European continent and its neighbourhood. "Regional cooperation", according to the German foreign minister, would include the North Sea, Northern Africa, Russia and the Gulf States (Steinmeier 2006a). By contrast, other member states, mainly from central Europe, insisted on the need to reinforce solidarity among European countries and reduce dependency on countries such as Russia, which exerted political pressure through the use of energy instruments. Poland was the standard-bearer of this discourse, especially after the approval of the North Stream gas pipeline under the Baltic Sea in September 2005, perceived as being directed against some member states' security of supply. ${ }^{15}$ However, in both cases, the referent objects were states' energy independence and their autonomy in vital economic and political matters. In no case did states propose a pooling of sovereignty or transfer of competencies to the EU level as a suitable option to alleviate the risks of external dependency, but rather, they favoured other forms of intergovernmental cooperation outside the EU framework.

Some of these forms of extra-EU intergovernmental cooperation are highlighted in the proposals for an 'energy NATO' and its rival 'energy OSCE', advanced by Poland and Germany respectively. The first was advanced by Poland in March 2006 and consisted of a 'European Energy Security Treaty', aimed at developing an absolutely new kind of political instrument linking states in the area by mutual energy security guarantees. The core of the Polish 'NATO energy' proposal would be a commitment "to cooperate in bringing assistance to a Party affected by restrictions in energy supplies, and to build and develop the necessary organisational and technical infrastructure designed to permit such cooperation". More specifically, the Energy Treaty would have a clause of mutual assistance among the Treaty signatories, as in the case of NATO, whereby "a threat to the energy security of one... will be a threat to the energy security of all...". In order to secure energy supply, the proposal also established the objective of diversification of energy sources and transit routes (Council of the European Union, 2006l). Quite to the contrary, Germany (Steinmeier 2006b) referred to regional cooperation on energy in the form of some kind of "energy OSCE", claiming that cooperative security strategy "can rely on the success of the Helsinki process". In this sense, German Foreign Minister Steinmeier stressed that there is no need for totally new instruments since "more importantly we have to revitalise the already existing forms of cooperation in energy policy context in the light of new challenges" (Steinmeier 2006b). Both of these proposals failed to be implemented but the residual outcome of Polish insistence on energy solidarity was the inclusion of this concept in the Lisbon Treaty, although the solidarity obligations were watered down in comparison to Poland's initial proposals. ${ }^{16}$

Other countries, such as France or Great Britain, were more cautious in presenting proposals on external measures for security of supply. For example, for France, in its 'Memorandum for revitalising European energy policy with a view to sustainable development' of January 2006, security of supply appeared to be more related to issues such as electricity interconnections, internal diversification of the energy mix, increased energy efficiency and use of renewable energies. Indeed, the Council debates for an 'Energy Policy for Europe' were framed more in terms of this internal dimension. As established by the Council, the means to develop a European Energy Policy were "investment, technological development, domestic and foreign trade, environment policy [...] employment, regional policy and particularly transport policy"

\footnotetext{
${ }^{14}$ The danger of these global dynamics was plainly formulated in expressions such as "global hunger for resources" and "world order politics threaten to collide" (Steinmeier 2006b).

15 In January 2006, Poland presented a joint position on the diversification of energy supplies to Central and East European countries, prepared together with the Czech Republic, Hungary and the Austrian EU Presidency, and also promoted a joint action plan (worked out with the Czech Republic, Slovakia, Austria, Hungary, Slovenia, Croatia and Romania) to reduce dependence on Russian natural gas (Documents referred to in Geder et al. 2006: 20)

${ }^{16}$ Art. 100 of the Treaty introduced the concept of "solidarity", stating that "without prejudice to any other procedures provided for in the Treaties, the Council, on a proposal from the Commission, may decide, in a spirit of solidarity between Member States, upon the measures appropriate to the economic situation, in particular if severe difficulties arise in the supply of certain products, notably in the area of energy".
} 
and only in the last position "foreign and development policy" (Council of the European Union 2006m).

However, what unites the discourses of all the member states is the emphasis on their competencies in determining their national strategies for security of supply. For example, Portugal insisted that the principle of subsidiarity "dictates that member states should keep the right to decide on the most appropriate solutions for implementing energy policies and measures, in order to take account of their specific situations" (Council of the European Union 2006d). Germany also stressed that "while a legal framework will be set at [the] EU level taking the subsidiarity principle into account, the choice of energy mix and general structure of energy supply as well as compliance with the legal framework will remain a matter of the Member States" (Council of the European Union 2006e). In the same vein, Spain stated that "improving the dependence-vulnerability relationship is the primary aim of Community action" while emphasizing the prerequisite of "preserving national sovereignty over energy sources and safeguard national preferences for the choice of energy-mix [...] for it to be otherwise would be a grave mistake" (Council of the European Union 2006h). In the French proposals, it might seem that European and member states' levels are blurred, but for France the origin of a European Energy Policy stems from the exchange of national energy plans. With this aim in mind, each member state should "identify the medium and long-term balance to be achieved between supply (production plus imports) and demand, and contribute to the drafting of national energy policies in which each Member State establishes a clear framework for the actions it aims to take to balance supply and demand" (Council of the European Union 2006b).

Contributions arguing for a Community-focused dimension of energy policy are in a clear minority. For example, the main concern for Italy was the lack of an adequate legal basis for more integrated policies, which would make energy a matter of shared competence between the Commission and the member states (Council of the European Union 2006c). In this respect, Belgium also insisted that "the time has come to boost Europe's influence in so strategic an area as Energy" and that "the pursuit of a European energy policy demands that Europe be able to speak with a single voice and brings its full economic political weight to bear in dialogue with third countries, both producer countries and consumer countries" (Council of the European Union 2006f).

In this context, it is not surprising that the Council's proposals for the EU's external energy relations underline the responsibility of member states, as shown in the various drafts of the document 'A New Energy Policy for Europe', where the ministers "call for a reinvigorated Energy policy for Europe, aiming at coherence between member states", their "sovereignty over primary energy source" and respect for "member states preferences for the choice of energy mix"; ensuring an utmost degree of consistency at the Community level "they should take due account of member states specific characteristics" (Council of the European Union 2006i) or "recalling the primary responsibility of member states in the event of supply crisis" (Council of the European Union 2006j).

Consequently, the conclusions of the Council meetings focused on the EU's internal and external measures on security of supply policy with much more ambiguity and vagueness than the other Community institutions. The initial debate within the Council confirmed the extreme caution in adopting any far-reaching decision. The Austrian Presidency in early 2006 maintained a prudent stance and hardly raised any new topics to be debated or extraordinary measures to be implemented (Council of the European Union 2006a). Therefore, it is comprehensible that after taking the opinion of other member states into consideration, the Presidency recognised that:

[...] regarding the regulatory framework it is worth noting that there are very few requests or suggestions for the development of new instruments, with the possible exception of measures related to energy efficiency and gas storage, while several delegations, [...], are pressing for a fuller implementation of the existing framework and, to that effect, more consistency in the remit of regulators throughout Europe (Council of the European Union 2006g). 
However, despite the initial reluctance of many member states to approve concrete proposals, especially when it came to establishing new institutional forms of cooperation, some ideas were finally adopted by the European Council in March 2007. European leaders agreed to base the European Energy Policy on internal measures such as the reinforcement and full implementation of the Internal Energy Market. They also agreed on the objective of 20 per cent of the overall energy mix in 2020 to be from renewable energy sources and stressed the relevance of energy efficiency in order to reduce primary energy consumption in 2020 by 20 per cent. Taking into account the indeterminacy of earlier proposals by the Council, the agreement on establishing concrete targets represents a significant political commitment. However, the Council dismissed the more ambitious and integrationist proposals from the Commission, such as establishing an EU regulatory agency to deal with energy policy.

As far as the external dimension of energy policy is concerned, no major proposals were adopted. The most remarkable, albeit timid, decisions of the European Council of March 2007 had to do with security of supply. It was agreed to establish more effective crisis response mechanisms to face the eventuality of a crisis in supply. However, the significance of these mechanisms is far from clear, given the carefully worded compromise that further mechanisms should be built "notably on existing mechanisms [...] taking into account the primary responsibility of Member States regarding their domestic demand" (Council of the European Union 2007: 18). The Council also approved the institutionalisation of the role of the network of energy security correspondents which had met informally for the first time after the Ukrainian-Russian energy crisis of January 2006. Likewise, the Commission's proposal of establishing an Energy Observatory within the Commission was adopted (Council of the European Union 2007: 18). Finally, the Council agreed that energy be included on the agenda of the EU's bilateral and regional external relationships.

In summary, the Council's proposals fail to reflect the positions adopted both by the European Commission and the European Parliament, particularly on the question of whether the EU is the most appropriate level to tackle energy related problems. Ironically, member states actually shared the views of both the Commission and the EP concerning the evolution of energy as a vital security concern. However, this security framing of energy is precisely what justified their reluctance to (1) transfer competencies to the supranational level and (2) increase the level of intergovernmental cooperation within the EU on these issues. Therefore, the member states' collective approach to a European Energy Policy was to continue "to do the same but better" and to achieve greater coherence through "better exploiting the synergies and complementarities between the various, internal and external, components of energy policy" (Council of the European Union 2006g).

\section{Conclusion}

This article has discussed the various discourses of the EU institutions and those member states that took an active role in the debate on energy security in order to understand why the final results of this debate failed to reflect the high securitizing rhetoric maintained by most of the actors involved. In this regard, we have argued that few significant measures were finally adopted towards a Common Energy Policy, although several proposals were put forward in this direction. Particularly, the Commission and the EP advanced proposals that, even though they were not entirely new, did envisage an important step towards further communitarisation of energy policy. Conversely, the novel decisions finally adopted by the Council mostly consisted of loose mechanisms for intergovernmental cooperation that would draw on already existing instruments.

Informed by securitization studies, this article has attempted to explain the reasons for this gap between highly securitizing discourse on the one hand, and, on the other, the lack of agreement on taking urgency or extraordinary measures to tackle the identified sources of insecurity. In the first place, we argued that differences in actors' approaches to energy 
security did not have to do with the definitions of the threats, which were similar in all discourses, but with their differing referent objects. Regarding the definitions of threats and risks, our analysis has shown that there was significant similarity between the different actors in terms of the way they were framing energy. The dominant discourse maintained that the sources of threat related to the market disturbances that changed the existing patterns of the global energy system. The main concern was related to the observation that, on the one hand, market-type energy relations no longer worked because they were progressively being substituted by both political and other kinds of unpredictable interferences in energy relations, such as natural disasters or terrorist attacks. Another widely-shared feature of the framing of energy security was its cross-sector nature; energy was framed both in terms of economic, environmental, societal and political concerns, even though different actors put special emphasis on particular sectors.

In contrast, major differences exist when it comes to the identification of the referent objects, that is to say, the things that are considered to be affected by threats. The participants in the energy security debate, in accordance with the expectations related to their institutional roles, emphasised different types of referent objects. Thus, in the European Commission's discourse, the national perspective was almost non-existent and the focus was on protecting the European economy or European integration and individuals, both consumers and citizens. The European Parliament widened the scope of referent objects further, ranging from the EU citizens' way of life to energy as a global good. Conversely, the European Council and particular member states put special emphasis on national energy systems and thus, their own competences and responsibilities to ensure their energy independence. This may hardly be surprising, but it reaffirms the fact that even in times of growing demand for cooperative governance at the EU level in the domain of energy, member states hardly perceive the EU as a unit of reference, and consequently do not trust the EU as the 'most appropriate locus' for dealing with energy problems. Unlike other policy domains, such as those in Justice and Home Affairs, where security discourses may have triggered uniting effects around the need to protect the EU's common borders and a common 'Area of Freedom, Security and Justice', no such powerful parallel can be found in the energy domain at the time being. As this article has sought to demonstrate, member states have emphasised the unit level (state) or sub-systemic level (not the EU, but the European or Euro-Atlantic community of countries). This is most clearly evident in the Polish and German proposals for an Energy NATO or an Energy OSCE.

Secondly, this article has highlighted the fact that the discourses of those actors pursuing further communitarisation of energy policies might have been ineffective precisely because of their appeal to security. Essentially, the framing of the external dimension of the energy policy in terms of security or geostrategic concern rendered the pledge for a greater role for the Community institutions more difficult. In this sense, we have argued that framing energy as a security issue contributed to a reinforcement of the discourses in favour of maintaining energy policies in a predominantly intergovernmental framework.

Finally, we should recall that although we have argued in this article that no major moves towards the establishment of a Common Energy Policy and/or an EU external energy policy have been made, the small steps that have been taken are not to be dismissed. The most illustrative of these steps was the introduction of a Title on 'Energy Policy' in the Lisbon Treaty, including a solidarity energy clause. This is a development that the Commission has been pursuing since 1990. In fact, it might be argued that the Commission and the Parliament's securitizing moves did have: (1) a mobilizing effect on the level of support among the member states for the measures that had already been implemented or prepared and (2) an impact on raising public awareness of the Community institutions' tasks. However, these gradual reforms in the field of energy could also be considered as a natural development through functional steps towards greater cohesion with both horizontal and vertical coordination of existing activities and, it could be argued, they do not constitute an exceptional course of action, as a more radical, successful securitization process would suggest. In this sense, it is important to remember that the Council already posited in 1974 
that the establishment of the then "new energy policy strategy for the Community", implied "close coordination of the positions of the member states of the Community which will enable it progressively to express a common viewpoint on energy problems vis-à-vis the outside world" (emphasis added) (Council of the European Communities 1974).

\section{References}

Balzacq, T. (2008). 'The Policy Tools of Securitization: Information Exchange, EU Foreign and Interior Policies', Journal of Common Market Studies, 46 (1), pp. 75-100.

Baran, Z. (2007). 'EU Energy Security: Time to End Russian Leverage', The Washington Quarterly, 30 (4), pp. 131-144.

Bigo, D. (1996). Polices en réseaux: L'expérience européenne. Paris: Presses de Sciences Po.

Bigo, D. and Guild, E. (eds.) (2005). Controlling frontiers: free movement into and within Europe. Aldershot [etc.]: Ashgate.

Bundesministerium der Verteidigung (2006). Weißbuch zur Sicherheitspolitik Deutschlands und zur Zukunft der Bundeswehr. Berlin.

Buzan, B., Wæver, O. and de Wilde, J. (1998). Security: A New Framework for Analysis. Boulder: Lynne Rienner.

Correljé, A. and van der Linde, C. (2006). 'Energy supply security and geopolitics: A European perspective', Energy Policy, 34 (5), pp. 532-543.

Commission/SG/HR for the European Council (2006). An External Policy to Serve Europe's Energy Interests. 15-16 June 2006, available at:

http://www.consilium.europa.eu/uedocs/cmsUpload/st09971.en06.pdf, last accessed 27 June 2008.

Commission of the European Communities (1972). The Community Energy Policy. Information. 1/72, 5 May 1972, Brussels: Commission of the European Communities, Press and Information General - Directorate, available at: http://aei.pitt.edu/7636/01/31735055262673 1.pdf, last accessed 27 June 2008.

Commission of the European Communities (1974). Towards a New Energy Policy Strategy for the European Community. COM (74) 550 final/2, 26 June 1974, available at: http://aei.pitt.edu/5190/01/001648 1.pdf, last accessed 27 June 2008.

Commission of the European Communities (2000). Green Paper. Towards a European strategy for the security of energy supply. COM (2000) 769 final, Brussels, 29 November 2000, available at: http://ec.europa.eu/energy/green-paper-energysupply/doc/green_paper_energy_supply_en.pdf, last accessed 1 July 2008.

Commission of the European Communities (2006a). Green Paper. A European Strategy for Sustainable, Competitive and Secure Energy. COM (2006) 105 final, Brussels, 08 March 2006, available at: $\quad$ http://ec.europa.eu/energy/green-paperenergy/doc/2006 0308 gp document en.pdf, last accessed 1 July 2008.

Commission of the European Communities (2006b). External energy relations - from principles to action. COM (2006) 590 final, Brussels, 12 October 2006, available at:

http://ec.europa.eu/energy/green-paperenergy/doc/2006_03_08_gp_document_en.pdf, last accessed 27 June 2008.

Commission of the European Communities (2007). An Energy Policy for Europe. COM (2007) 1 final, Brussels, 10 January 2007, available at:

http://ec.europa.eu/external relations/energy/docs/com06 590 en.pdf, last accessed 27 June 2008.

Commission of the European Communities (2002). Communication from the Commission to the Council and the European Parliament. Final report on the Green Paper 'Towards a European strategy for the security of energy supply'. COM(2002) 321 final, Brussels, 26 June 2002, available at: 
http://eur-lex.europa.eu/LexUriServ/LexUriServ.do?uri=COM:2002:0321:FIN:EN:PDF, last accessed 27 June 2008.

Council of the European Communities (1974). 'Council Resolution of 17 September 1974 concerning a new energy policy strategy for the Community'. Official Journal of European Communities. C 153 , 09 July 1975, pp. 1-2, available at: http://eurlex.europa.eu/LexUriServ/LexUriServ.do?uri=CELEX:31975Y0709(01):EN:HTML, last accessed 27 June 2008.

Council of the European Union (2006a). A New Energy Policy for Europe; The functioning of the internal gas and electricity market - Approach and Handling. 5401/06, Brussels, 16 January 2006, available at:

http://register.consilium.europa.eu/pdf/en/06/st05/st05401.en06.pdf, last accessed 1 July 2008.

Council of the European Union (2006b). French Memorandum for revitalising European energy policy with a view to sustainable development. 5724/06, Brussels, 26 January 2006, available at: http://register.consilium.europa.eu/pdf/en/06/st05/st05724.en06.pdf, last accessed 1 July 2008.

Council of the European Union (2006c). New Energy Policy (Initial contribution from the Italian delegation to the debate on a New Energy Policy for Europe). Italian Delegation, 5944/06, Brussels, 2 February 2006, available at:

http://register.consilium.europa.eu/pdf/en/06/st05/st05944.en06.pdf, last accessed July 2008.

Council of the European Union (2006d). New Energy Policy Comments on 5401/06 of 16 January 2006 'A new Energy policy for Europe'. [Portuguese Delegation], 5977/06, Brussels, 3 February 2006, available at:

http://register.consilium.europa.eu/pdf/en/06/st05/st05977.en06.pdf, last accessed 1 July 2008.

Council of the European Union (2006e). New Energy Policy (German key issues paper on energy policy in the EU). 6009/06, Brussels, 3 February 2006, available at:

http://register.consilium.europa.eu/pdf/en/06/st06/st06009.en06.pdf, last accessed 1 July 2008.

Council of the European Union (2006f). New Energy Policy (Contribution from Belgium on the new energy policy of the European Union). 6014/06, Brussels, 3 February 2006, available at: http://register.consilium.europa.eu/pdf/en/06/st06/st06014.en06.pdf, last accessed 1 July 2008.

Council of the European Union (2006g). New Energy Policy. Preparation of a contribution of the Energy Ministers to the 2006 Spring European Council. Key issues. 5814/06, Brussels, 6 February 2006, available at:

http://register.consilium.europa.eu/pdf/en/06/st05/st05814.en06.pdf, last accessed 1 July 2008.

Council of the European Union (2006h). New Energy Policy (Contribution from Spain to the Austrian Presidency's Note on the New European Energy Policy). 6084/06, Brussels, 7 February 2006, available at:

http://register.consilium.europa.eu/pdf/en/06/st06/st06084.en06.pdf, last accessed 1 July 2008.

Council of the European Union (2006i). New Energy Policy - Preparation of a contribution of the Energy Ministers to the 2006 Spring European Council. 6143/06, Brussels, 13 February 2006, available at:

http://register.consilium.europa.eu/pdf/en/06/st06/st06143.en06.pdf, last accessed 1 July 2008.

Council of the European Union (2006j). Council conclusions: "A New Energy Policy for Europe" Contribution of the Energy Ministers to the 2006 Spring European Council. 6143/1/06/REV 1, Brussels, 17 February 2006, available at: http://register.consilium.europa.eu/pdf/en/06/st06/st06143-re01.en06.pdf, last accessed 1 July 2008.

Council of the European Union (2006k). Council conclusions: 'A New Energy Policy for Europe' Contribution of the Energy Ministers to the 2006 Spring European Council. 6878/06, Brussels, 2 March 2006, available at: 
http://register.consilium.europa.eu/pdf/en/06/st06/st06878.en06.pdf, last accessed 1 July 2008.

Council of the European Union (2006l). Proposal for a European Energy Security Treaty presentation by the Polish delegation (Poland's non-paper: Outline of the European Energy Security Treaty). 7160/06, Brussels, 9 March 2006, available at:

http://register.consilium.europa.eu/pdf/en/06/st07/st07160.en06.pdf, last accessed 1 July 2008.

Council of the European Union (2006m). Brussels European Council 23-24 2006. Presidency Conclusions. Brussels, 23 and 24 March, 7775/1/06 REV 1, Brussels, 18 May 2006, available at: http://register.consilium.europa.eu/pdf/en/06/st07/st07775re01.en06.pdf, last accessed 1 July 2008.

Council of the European Union (2007). Brussels European Council - 8/9 March. Presidency Conclusions. 7224/1/07 REV 1, Brussels, 2 May 2007, available at:

http://register.consilium.europa.eu/pdf/en/07/st07/st07224-re01.en07.pdf, last accessed 1 July 2008.

'Decision No. 1364/2006/EC of the European Parliament and of the Council of 6 September 2006 laying down guidelines for trans-European energy networks and repealing Decision 96/391/EC and Decision No 1229/2003/EC'. Official Journal of the European Union, L 261, 22 September 2006, available at: http://eurlex.europa.eu/LexUriServ/LexUriServ.do?uri=OJ:L:2006:262:0001:0023:EN:PDF, last accessed 1 July 2008.

De Goede, M. (2008). 'The Politics of Preemption and the War on Terror in Europe', European Journal of International Relations, 14 (1), pp. 161 - 185.

Dimas, S. (2005). Climate Change: The Urgency of the Problem. Speech/05/309, Brussels, 31 May 2005, available at:

http://europa.eu/rapid/pressReleasesAction.do?reference=SPEECH/05/309\&format=H TML\&aged $=1$ \&language $=E N \&$ guilanguage $=e s$, last accessed 1 July 2008.

Dimas, S. (2006a). A Pan-European Energy Policy for the internal market or markets to promote development. Speech/06/666, European Parliament, 8 November 2006, available at:

http://europa.eu/rapid/pressReleasesAction.do?reference=SPEECH/06/666\&format=H TML\&aged $=1$ \&language $=E N \&$ guiLanguage $=e n$ last accessed 1 July 2008.

Dimas, S. (2006b). Environment, Energy and Security. Speech/06/671, Brussels, 9 November 2006, available at:

http://europa.eu/rapid/pressReleasesAction.do?reference=SPEECH/06/671\&format=H TML\&aged=1\&language=EN\&guiLanguage $=e n$ last accessed 1 July 2008.

European Commission, Directorate-General for Energy and Transport (2008). European Energy and Transport. Trends to 2030 - Update 2007. Luxembourg: Office for Official Publications of the European Communities.

European Parliament (2006a). European Parliament resolution on security of energy supply in the European Union. P6 TA(2006)0110, Brussels, 23 March 2006, available at: http://www.europarl.europa.eu/sides/getDoc.do?type=TA\&reference=P6-TA-20060110\&language=EN\&ring=B6-2006-0192, last accessed 1 July 2008.

European Parliament (2006b). European Parliament resolution on a European strategy for sustainable, competitive and secure energy - Green paper. P6 TA(2006)0603, Strasbourg, 14 December 2006, available at:

http://www.europarl.europa.eu/sides/getDoc.do?pubRef=-//EP//TEXT+TA+P6-TA2006-0603+0+DOC+XML+V0//EN\&language=EN, last accessed 1 July 2008.

European Parliament (2006c). 'Debate about 'Security of energy supply in the European Union' (debate), 22 March 2006. available at:

http://www.europarl.europa.eu/sides/getDoc.do?type=CRE\&reference=20060322\&se condRef $=\mid T E M-012$ \&language $=E N \&$ ring $=P 6-R C-2006-0189$, last accessed 16 June 2008.

Geden, O., Marcelis, C. and Maurer, A. (2006). 'Perspectives for the European Union's External Energy Policy. Discourses, Ideas and Interests in Germany, the UE, Poland and France', Working Paper. 2006/17, December, Berlin: Stiftung Wissenschaft und Politik.

Grevi, G. (2006). Seminar on 'CFSP and Energy Security', 23 October 2006, Paris: EU Institute for Security Studies. 
Guild, E. (2008). 'The Uses and Abuses of Counter-Terrorism Policies in Europe:The Case of the 'Terrorist Lists", Journal of Common Market Studies, 46(1), pp. 173-93.

Harks, E. (2006). 'The Conundrum of Energy Security - Gas in Eastern and Western Europe', The International Spectator, 41 (3), pp. $47-58$.

Higashino, A. (2004). 'For the Sake of 'Peace and Security'? The role of Security in the European unon Enlargement Eastwards', Cooperation and Conflict, 39 (4), pp. 347-368.

Huysmans, J. (2006). The Politics of Insecurity. Fear, Migration and Asylum in the EU. London: Routledge.

Huysmans, J. (2000). 'The European Union and the Securitization of Migration', Journal of Common Market Studies, 38 (5), pp. 751-777.

Jeandesboz, Julien (2007). 'Labeling 'neighbourhood': towards a genesis of the European neighbourhood policy', Journal of International Relations and Development, 10 (4), pp. $387-416$.

Kroes, N. (2006a). A new energy policy for a new era. Speech/06/648, Brussels, 30 October 2006, available at:

http://europa.eu/rapid/pressReleasesAction.do?reference=SPEECH/06/648\&format=H

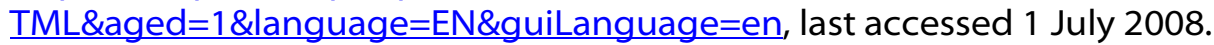

Kroes, N. (2006b). The need for a renewed European energy policy. Speech/06/541, London, 28 September 2006, available at:

http://europa.eu/rapid/pressReleasesAction.do?reference=SPEECH/06/541\&format=H TML\&aged $=1$ \&language $=E N \&$ guilanguage $=e n$, last accessed 1 July 2008.

Mañé-Estrada, A. (2006). 'European energy security: Towards the creation of the geo-energy space', Energy Policy, 34 (18), pp. 3773 - 3786.

Matláry, J. H (1997). Energy Policy in the European Union. Houndmills, Basingstoke: MacMillan Press.

Moussis, N. (2004). Guide to European Policies. 10th revised edition, Reixensart: European Study Service.

Piebalgs, A. (2006a). The European initiative on Energy Efficiency. Joint Meeting ITRE - National Parliaments. Speech/06/31, Brussels, 24 January 2006, available at:

http://europa.eu/rapid/pressReleasesAction.do?reference=SPEECH/06/31\&format=HT ML\&aged $=1$ \&language $=E N \&$ guiLanguage $=e n$, last accessed 1 July 2008.

Piebalgs, A. (2006b). Towards a closer EU-China cooperation in the field of Energy. Speech/06/105, Shanghai, 20 February 2006, available at:

http://europa.eu/rapid/pressReleasesAction.do?reference=SPEECH/06/105\&format $=\mathrm{H}$ TML\&aged $=1$ \&language $=E N \&$ guiLanguage $=e n$, last accessed 1 July 2008.

Piebalgs, A. (2006c). A Common Energy Policy for Europe. Speech/06/161, Brussels, 9 March 2006, available at:

http://europa.eu/rapid/pressReleasesAction.do?reference=SPEECH/06/161\&format $=\mathrm{H}$ TML\&aged $=1$ \&language $=E N \&$ guiLanguage $=e n$, last accessed 1 July 2008.

Piebalgs, A. (2006d). Challenges and Perspectives of the EU energy policy. Speech/06/285, Brussels, 10 May 2006, available at:

http://europa.eu/rapid/pressReleasesAction.do?reference=SPEECH/06/285\&format=H TML\&aged $=1$ \&language $=E N \&$ guilanguage $=e n$, last accessed 1 July 2008.

Piebalgs, A. (2006e). Nabucco Pipeline - Searching for Alternative Routes for our Gas Supply. Speech/06/413, Brussels, 26 June 2006, available at:

http://europa.eu/rapid/pressReleasesAction.do?reference=SPEECH/06/413\&format=H TML\&aged $=1$ \&language $=E N \&$ guiLanguage $=e n$, last accessed 1 July 2008.

Piebalgs, A. (2006f). 'External projection of the EU internal energy market', in Towards an EU External Energy Policy, The 2006 Brussels Conference, 20th and 21st November 2006. Brussels: European Communities, pp. 21-24.

Piebalgs, A. (2006g). EU-India a New Energy Era. Speech/06/234, New Delhi, 7 April 2006, available at:

http://europa.eu/rapid/pressReleasesAction.do?reference=SPEECH/06/234\&format=H TML\&aged $=1$ \&language $=E N \&$ guilanguage $=e n$ last accessed 1 July 2008.

Steinmeier, F.-W. (2006a). Russland, Europa und die Welt - Perspektiven der Zusammenarbeit in globalen Sicherheitsfragen. 42 Munich Conference for Security Politics. München, 5 February 2006, available at: http://www.auswaertiges- 
amt.de/diplo/de/Infoservice/Presse/Reden/2006/060205-MuenchenKonferenz.html, last accessed 1 July 2008.

Steinmeier, F.-W. (2006b). 'Energie-Außenpolitik ist Friedenspolitik', Handelsblatt, 23 March 2006.

Steinmeier, F.-W. (2006c). Internationale Aspekte der Energiepolitik. Discourse of the Foreign Minister at the Energy Summit of the Federal Government. Berlin, 9 October 2006.

Wæver, O., Buzan, B., Kelstrup, M. and Lemaitre, P. (eds.) (1993). Identity, Migration and the New Security Agenda in Europe. London: Pinter Publisher.

Weisser, H. (2006). 'The security of gas supply a critical issue for Europe?', Energy Policy, 35 (1), pp. $1-5$.

Westphal, K. (2006). 'Energy Policy between Multilateral Governance and Geopolitics: Whither Europe?', Internationale Politik und Gesellschaft, 4, pp. $44-62$.

Yergin, D. (2006). 'Ensuring Energy Security', Foreign Affairs, 85 (2), pp. $69-82$. 